\title{
[一般講 演]
}

\section{（23）SPS法による選炭廃水中の石炭回収試験（第 1 報）}

(財) 石炭技術研究所第 2 研究部加工利用研究室 村 田遈 詮

\section{1. まえがき}

選炭廃棄物の有効処理対策の一つとして, 選炭廃水スラッシか ら石炭分のみを分離回収し，原燃料としてエネルギー資源の有効 活用を図る目的で当試験を実施した。

凝集剂未添加*の赤平炭鉱選炭廃水および赤平特粉等を対象と して, 試験規模 2 と回程度のバッチ試験等を行ない,インペラ回 転数、造粒時間，バインダ添加量（バインダ $\mathrm{A}$ 重油）と造粒性と の関連性を把握した。

\section{2. 試 験 装}

\section{2・1S P Sハッチ式試験装置}

試験装置は第 1 図に示す通りである。インペラは同図に示した ように 5 種あるが，当試験では第 2 図に示す $135 \mathrm{~mm} \phi$ のすを
使用した。

$$
\text { 3. 試 験 試 料 }
$$

\section{3・ 1 赤平炭鉣選炭廃水}

廃水固形物の粒度別灰分分析值小よび工業分析值は，第 1 表, 第2 表に示す通りである。2 $50 \mu$ の粒度分布は第 3 図に示す。

この粒度分布図は米国コールターエレクトロニクス社のT A II 型粒度分析器によるすので, 同社の日本代理店科機に試験依 頼して得たるのである。

試験に際しては固形物濃度を $5 \%$ 亿調整した。

$3 \cdot 2$ 赤平特粉

赤平特粉 $(-25 \mathrm{~mm})$ を小型口ッドミルで粉碎し, $-200 \mathrm{mesh}$ 通過分 $80 \%$ 以上のものを使用した。粒度分布を第 4 図に, 工業分 析值を第 3 表に示す。試験に際しては固形物濃度 $5 \%$ のスラリー に調整した。

\section{4. 試駼}

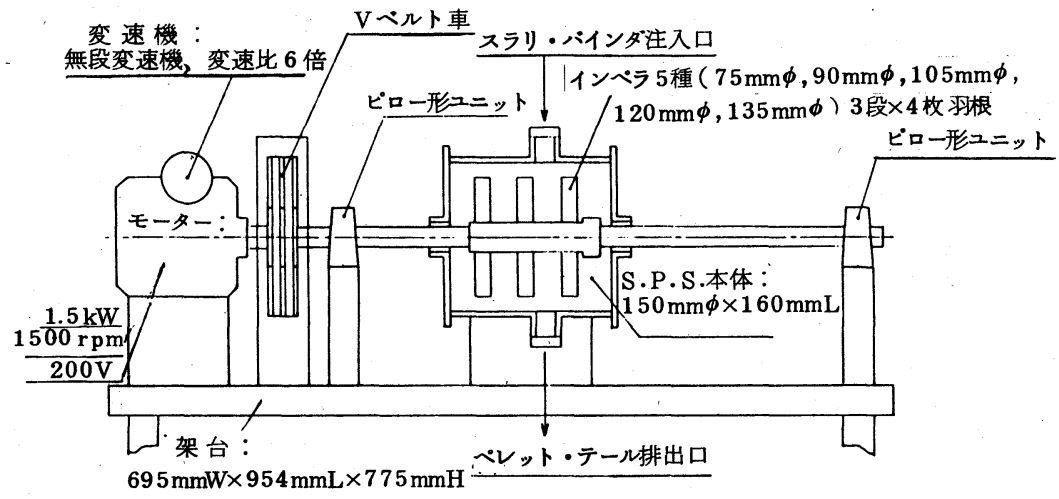

第1図 S P S バゥチ式試験装置

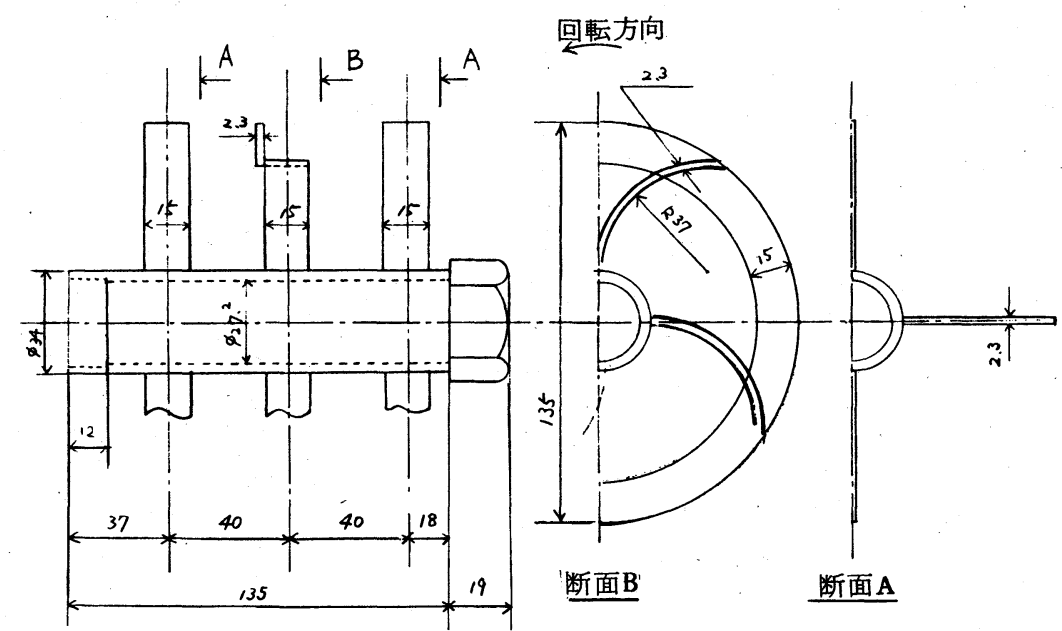

第 2 図 バッチ式用インペラ

\section{4・1 赤平廃水を対象とした試験} インペラ回転数 $(n)$, 造粒時間 $(t)$, バ インダ添加量 $(\Delta V)$ をそれぞれ 3 水準 $(n$ : $1000 \mathrm{rpm}, 1400 \mathrm{r} \mathrm{pm}, 1800 \mathrm{rpm}, t$ : 40 分, 60 分, 80 分. $\Delta V: 280 \mathrm{e}_{\mathrm{t}}^{* *}$

第 1表 赤平廃水固形物粒度別扊分測定值

\begin{tabular}{|c|c|c|}
\hline 粒度 $\mu$ 項 & $\begin{array}{c}\text { 重量割合 } \\
\text { W\% }\end{array}$ & 灰 $\%$ 分 \\
\hline $250 \sim 149$ & 0.23 & 14.0 \\
\hline $149 \sim 74$ & 1.15 & 4.6 \\
\hline $74 \sim 44$ & 3.39 & 8.5 \\
\hline-44 & 95.23 & 59.8 \\
\hline 計 & 100.00 & $\begin{array}{l}57.3 \text { 計算値 } \\
57.5 \text { 央測值 }\end{array}$ \\
\hline
\end{tabular}

第 2 表 赤平廃水固形物工業分析値

\begin{tabular}{|c|c|c|}
\hline$I$ & 水 分 $\%$ & 4.0 \\
\hline 業 & 分 \% & 55.9 \\
\hline 分 & 発 分 \% & 16.5 \\
\hline 析 & 固 定炭素 \% & 23.6 \\
\hline 発 & 熱 量 $\mathrm{kcal/kg}$ & 2,690 \\
\hline
\end{tabular}

第3表 赫特粉工業分析値

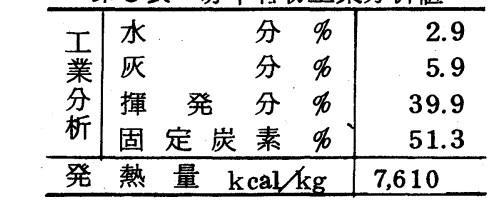

*** 純炭 $\mathbf{t}$

* 凝集剤添加資料はバインタ油に濡れにくくなるためか, 造粒しない。 


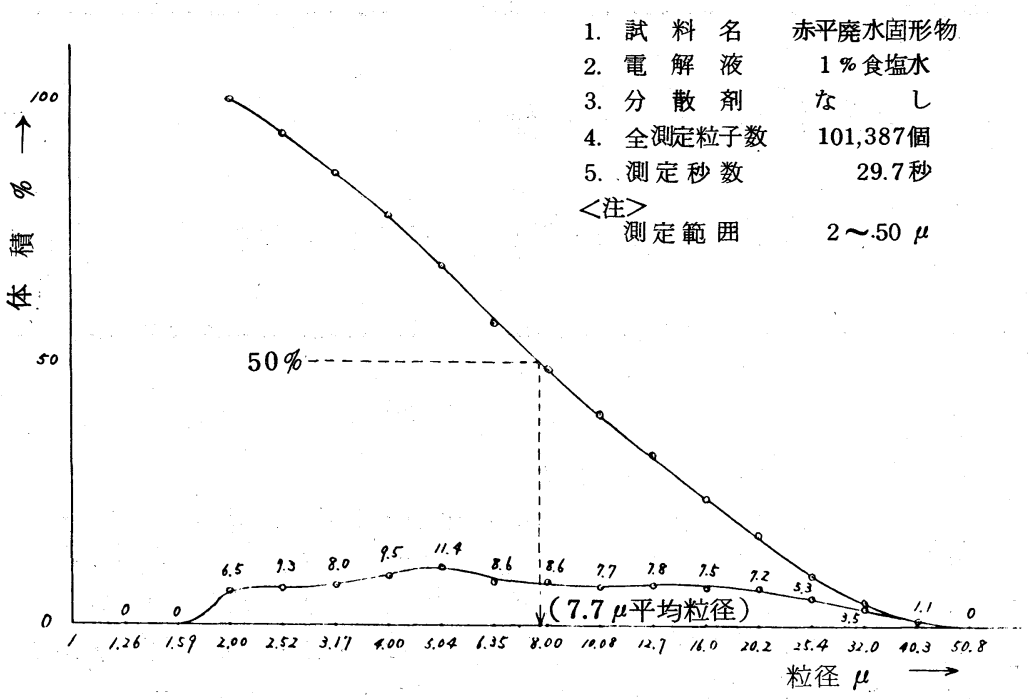

第 3 図 赤平廃水固形物粒度分布

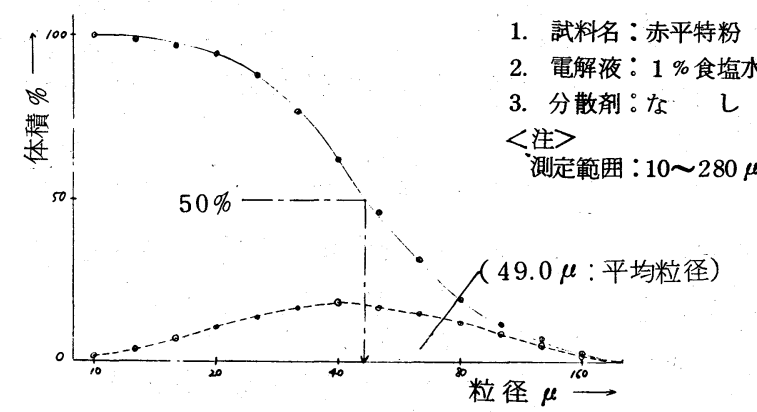

第 4 図 赤平特粉粒度分布

$360 \ell / t, 440 \ell / t)$ とつて, 計 27 個の試験をした。

第 4 表はその結果である。

\section{4・2 赤平特粉を対象とした試験}

石炭の造粒に必要な前記の $n, t, d V$ 亿関する知見をより的確 飞得るため，灰分の少ない赫平特粉を対象に， $n, t, \Delta V$ をそれ ぞれ 3 水準 $(n, t$ は $4 \cdot 1$ 試験 と同梯, $\Delta V: 220 \ell / \mathrm{t}, 300$ $\ell / t, 380 \ell / t)$ とつて, 計 27 個の試験をした。

第 5 表はその結果である。

4・3 赤平廃水に赤平特粉を添加したものを対象とした試験 $n$ を $1400 \mathrm{rpm} K, \Delta V$ を $300 \ell / \mathrm{t}$ 亿規定し, 赤平廃水スラリー に赤平特粉を順次加えた混合スラリーでの造粒性に関する知見を 得る目的で, $t$ をバラメータとした試験をした。混合スラリーの 総固形物濃度は $5 \%$ 亿調整した。

第 6 表はその結果である。

\section{4・4 分析に供する前のペレットの事前処理手順}

(1) ペレットを $0.10 \mathrm{~mm}$ 目のふるいに取り, 水をつてベット に移し計量する。

（2）付着水をもったペレットを $107^{\circ} \mathrm{C}$ 亿設定した定温乾燥器に 入れ 2 時間乾燥し, 乾燥ペレットを計量する。 ((1)の重量との差を 付着水分とみなす。油分の蒸発は考虑しない。油分の蒸発はシャ ーレ*に A 重油を $10 \mathrm{~g}$ 程度入れたブランクテストで, $5.6 \%$ 程度 である)。

(3) 乾燥ペレットをふるい目 $4.76 \mathrm{~mm}, 4.00 \mathrm{~mm}, 2.83 \mathrm{~mm}, 2.00$ $\mathrm{mm}, 1.19 \mathrm{~mm}, 0.50 \mathrm{~mm}$ のふるけを使用し，7区分にふるい分けす る。

*シャーレの寸法 $60 \mathrm{~mm} \phi \times 30 \mathrm{mmH}$

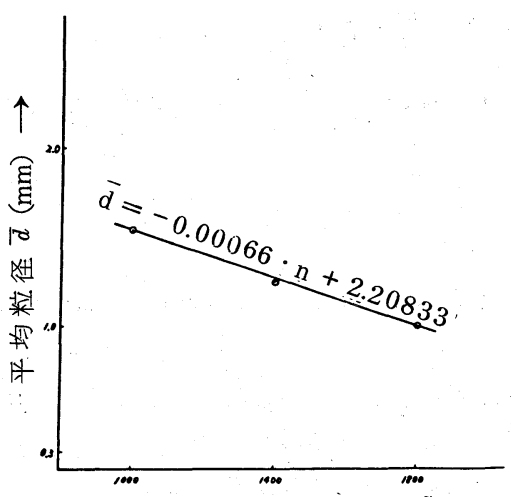

インペラ回転数 $n(\mathrm{rpm}) \rightarrow$

1. 試験試料：赤平特粉

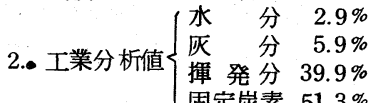

3. 造粒条件

スラリー濃度 $\quad 5.0 \%$ インペラー径 $135 \mathrm{~mm}$ ハインダ添加量 $300 \ell / \mathrm{t}$ 純炭 (平均値) 造 粒時間 $60 \mathrm{~min}$ (平均値)

第 5 図 インペラ回転数 $n$ とペレット 平均粒径 $\bar{d}$ の関係

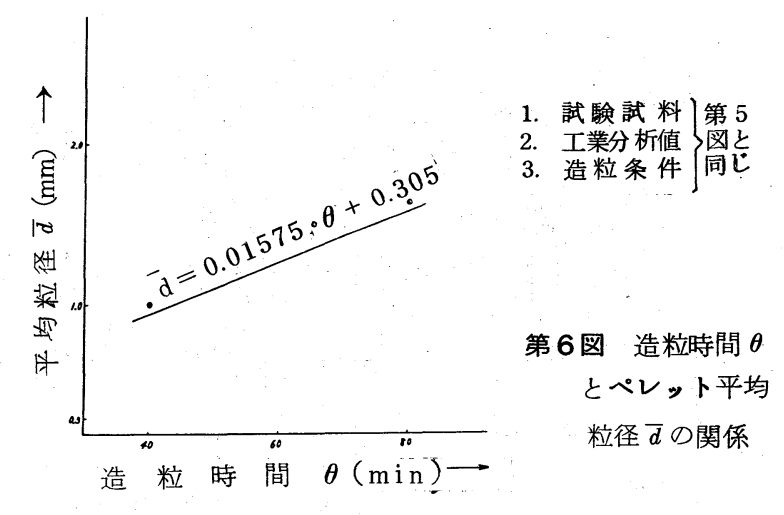

（4）ふるい分けの終つたペレットを二分し，それぞれすり鉢で 潰す。一方は分析に供し，他方はn一へキサンで脱油する。

（5）油分を $\mathrm{n}$ ーヘキサン $(50 \sim 100 \mathrm{~m} \ell$ 程度）で抽出したのち汇 紙（東洋汇紙N.5 A）により汇過する。

（6）汇紙上の脱油産物を常温乾燥し，分析に供する。

\section{5. 試験 結果の考 察}

試験の結果, インペラ回転数, 造粒時間, パインダ添加量と造 粒性との関連性につを，次のよらな傾向があることがわかつた。

（1）赤平廃水中（固形物兏分 $60 \%$ 前後）の微粉炭を造粒与るた めには, 延回転数 (回転数と造粒時間との積) は, $80 \times 10^{3}$ 回転程 度以上を必要とする (バインダ量： $300 \ell / \mathrm{t}$ 程度)。

(2) インペラ回転数の増大はペレットの平均粒径を小さくする (第 5 図《示す)。

（3）造粒時間の増大はペレットの平均粒径を大をくする（第 6 図示示)。

（4）延回転数の増大はペレットの平均粒径を大をくする（第 7 図に示す)。従つて，(2)、(3)を考虑すると，造粒時間の影響がより 強くでるといえる。

（5）ハヘンダ添加量の増大はペレットの平均粒径を大きくする (第 8 図に示す)。

（6）回転数の 3 乗と造粒時間との積（付加エネルギーに相当す 


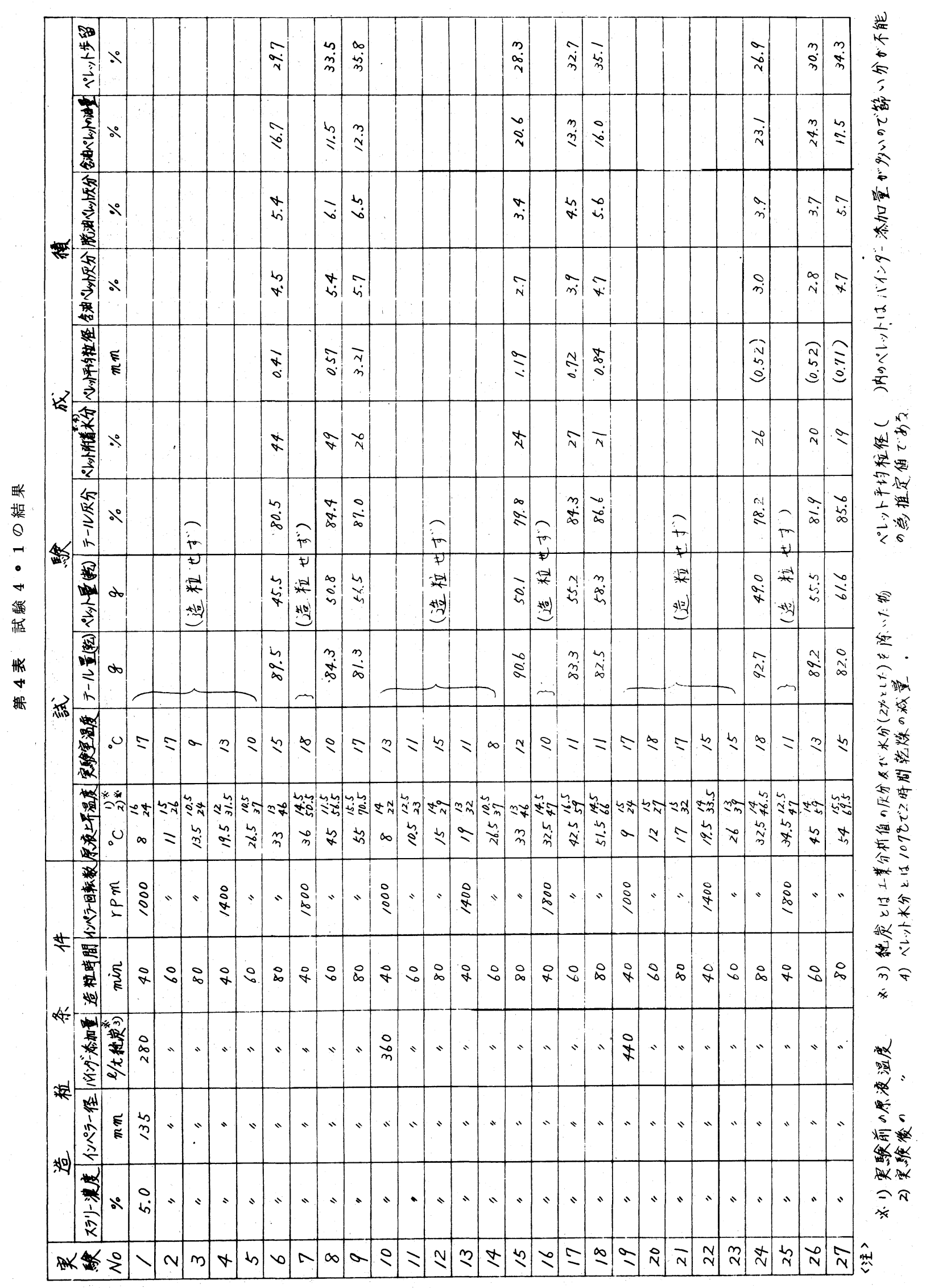




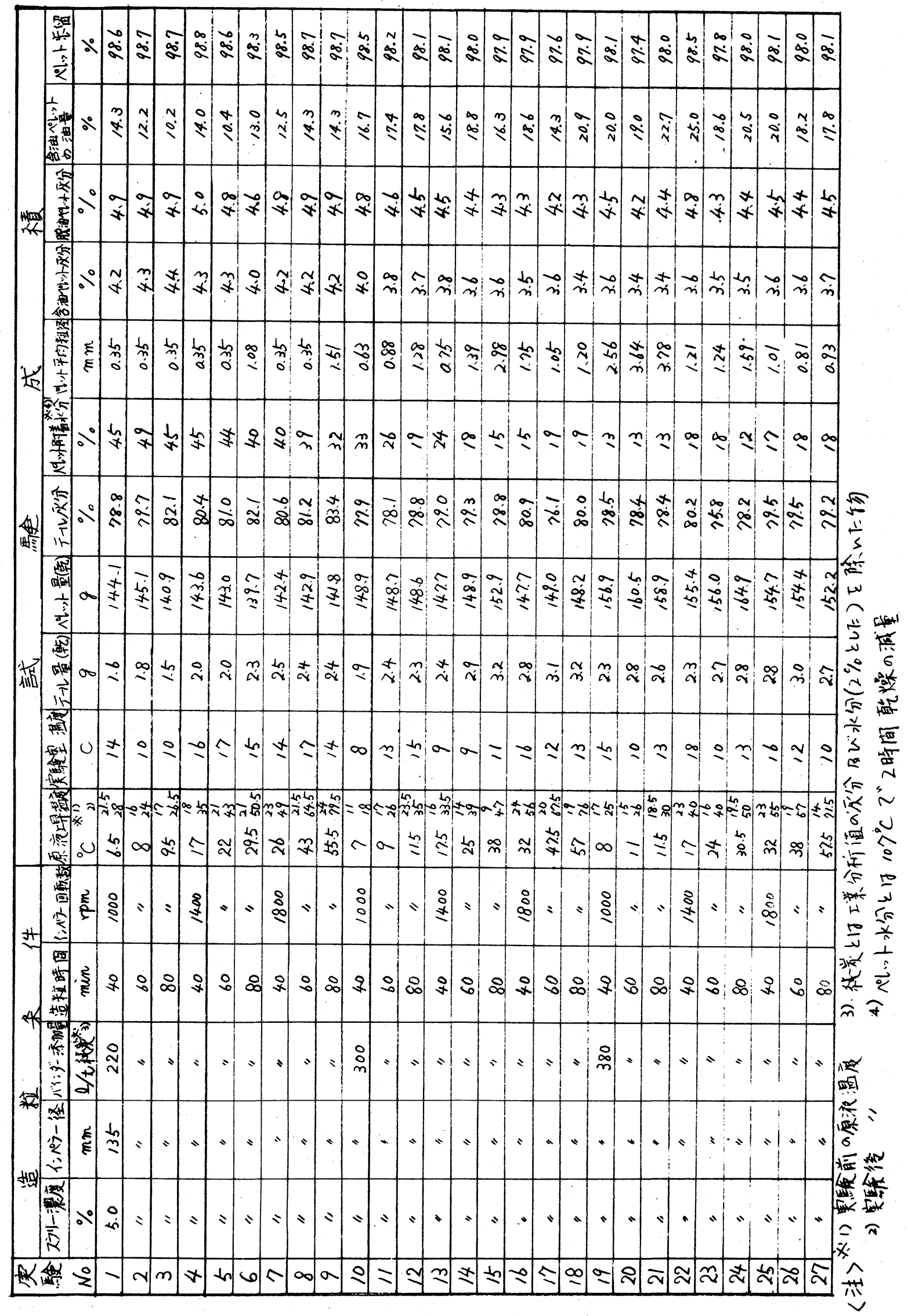




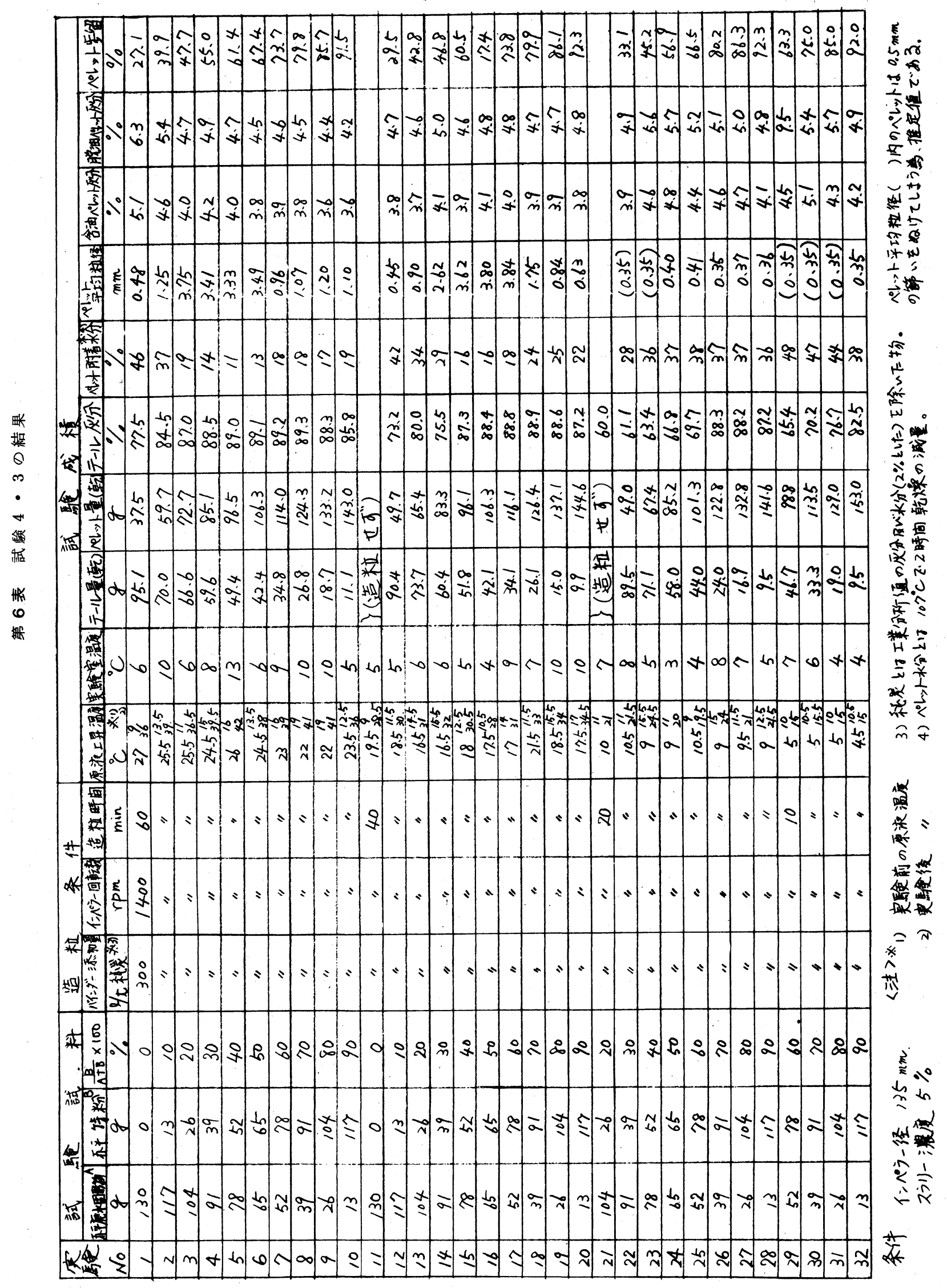



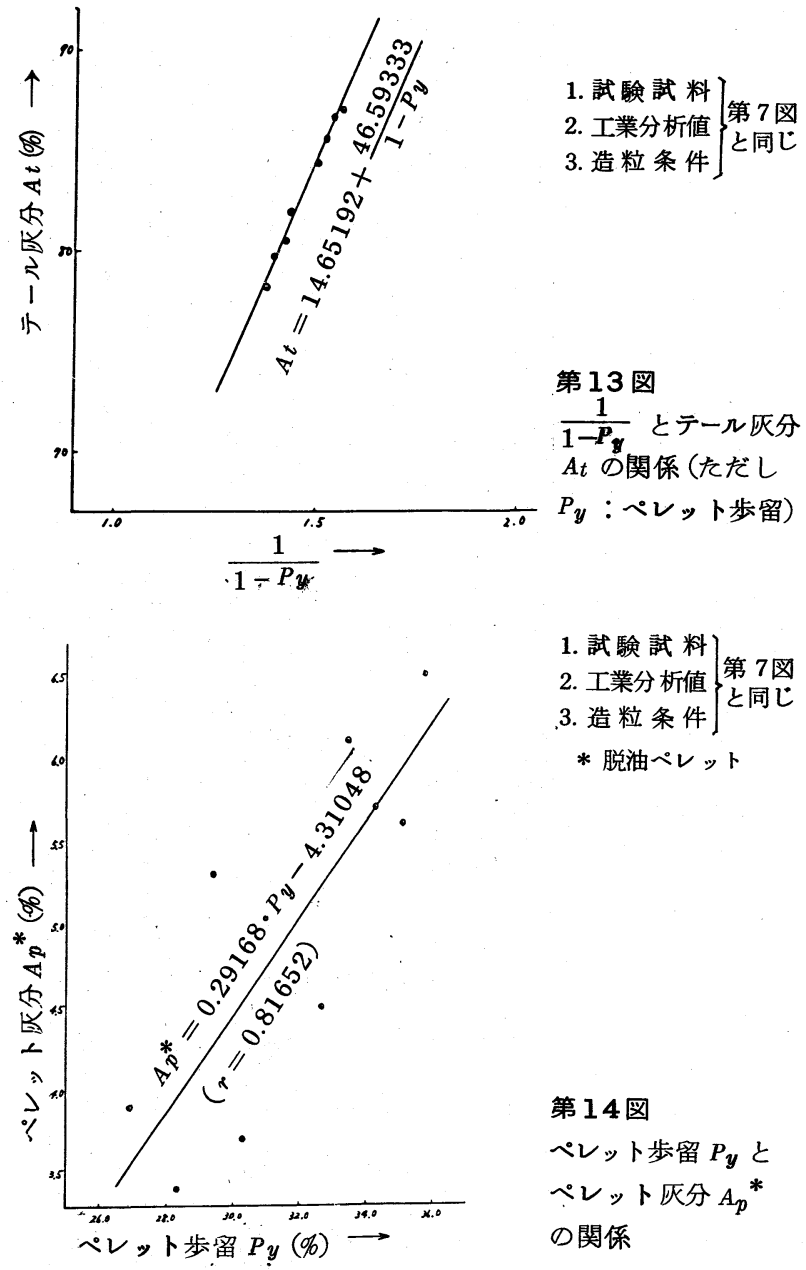

1. 試験試料

2. 工業分析値 第 7 図

3. 造粒条件

* 脱油ペレット

第 14 図

ペレット歩留 $P_{\boldsymbol{y}}$ と ペレット灰分 $A_{p}{ }^{*}$ の関係

表面の濡れについて, 対象となる炭種との関係を知る (52年度に 予備試験 一 接触角測定試験 —をしている。第 16 図は, 予備試 験よりの知見である)。

(2) 同じく微粉炭とバインダの付着仕事の重要因子であるバイ ンダと水との界面張力について，対象となるバインダとの関係を 知る ( 52 年度に予備試験をしてらる)。

(3) バインダの分散状態をなんらかの方法で把握する。

以上の 3 点は液の年温状態，熱バランスの大きく異なるバッチ 式と連続式とでは大幅違つてくるので, 事前調査として久くこ とのでをないてとがらである。

従つて, 53 年度はての 3 点をすず把握し，その知見をもとにし て, 連続試験を実施する予定である。

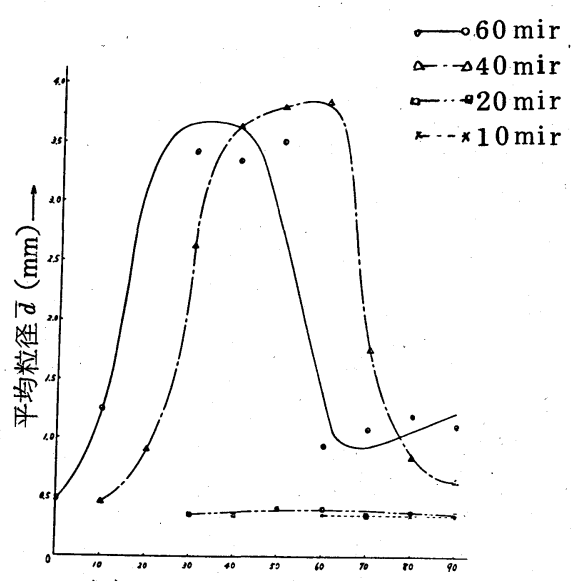

赤平廃水固形物中の赤平特粉の混合割合 $(\%) . \rightarrow$

1. 試験試料： 赤平廃水固形物・赤平特粉

2. 工業分析值：水 分 $4 \% \quad \downarrow$ $\begin{array}{llr}\text { 瓜 分 } & 55.9 \% & 5.9 \% \\ \text { 揮 発分 } & 16.5 \% & 39.9 \% \\ \text { 固定麦素 } & 23.6 \% & 51.3 \%\end{array}$

3. 造粒条件 : ジインダ添加量 $300 / \mathrm{t}$ 純炭 インペラ回転数 $1400 \mathrm{r} \mathrm{pm}$ $\begin{array}{ll}\text { スラリー濃度 } & 5.0 \% \\ \text { インペラー径 } & 135 \mathrm{~m}\end{array}$

第 15 図 赤平廃水固形物の品位の増大と平均粒径 $\bar{d}$ の関係

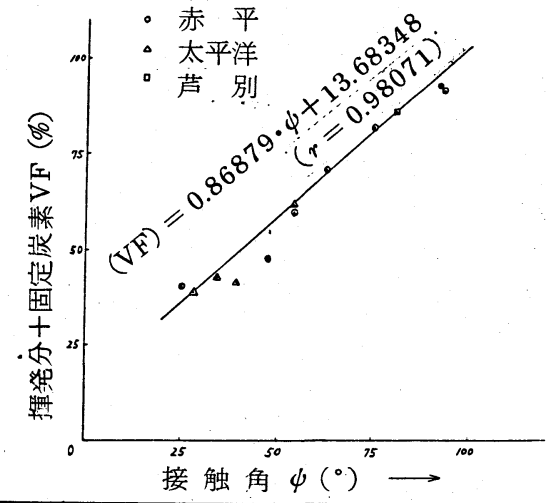

\begin{tabular}{|c|c|c|c|c|}
\hline 赤 平 & $\begin{array}{l}\text { 赤平廃水固形物 } \\
\text { 赤平 } 5 \\
\text { 赤 平 特 粉 } \\
\text { 赤 平 } 50 \text { 粉 }\end{array}$ & 0 粉 $\begin{array}{r}(-1.3) \\
\quad(1.3 \sim 1 . \\
(1.4 \sim 1.5 \\
\end{array}$ & $\begin{array}{l}\text { 4) }(1.5 \\
.5) \\
\end{array}$ & $\begin{array}{l}\sim_{1.6} \\
\sim\end{array}$ \\
\hline 太平洋 & 太平洋 No.1, NQ2, No. 3 & シック゚ナート & 沈澱池 & $\begin{array}{l}\text { 回収水 } \\
\text { 固形物 }\end{array}$ \\
\hline 芦 別 & 声 別 50 粉 & & & \\
\hline
\end{tabular}

第 16 図 水に対する接触角 $\rho$ と純炭分の関係 

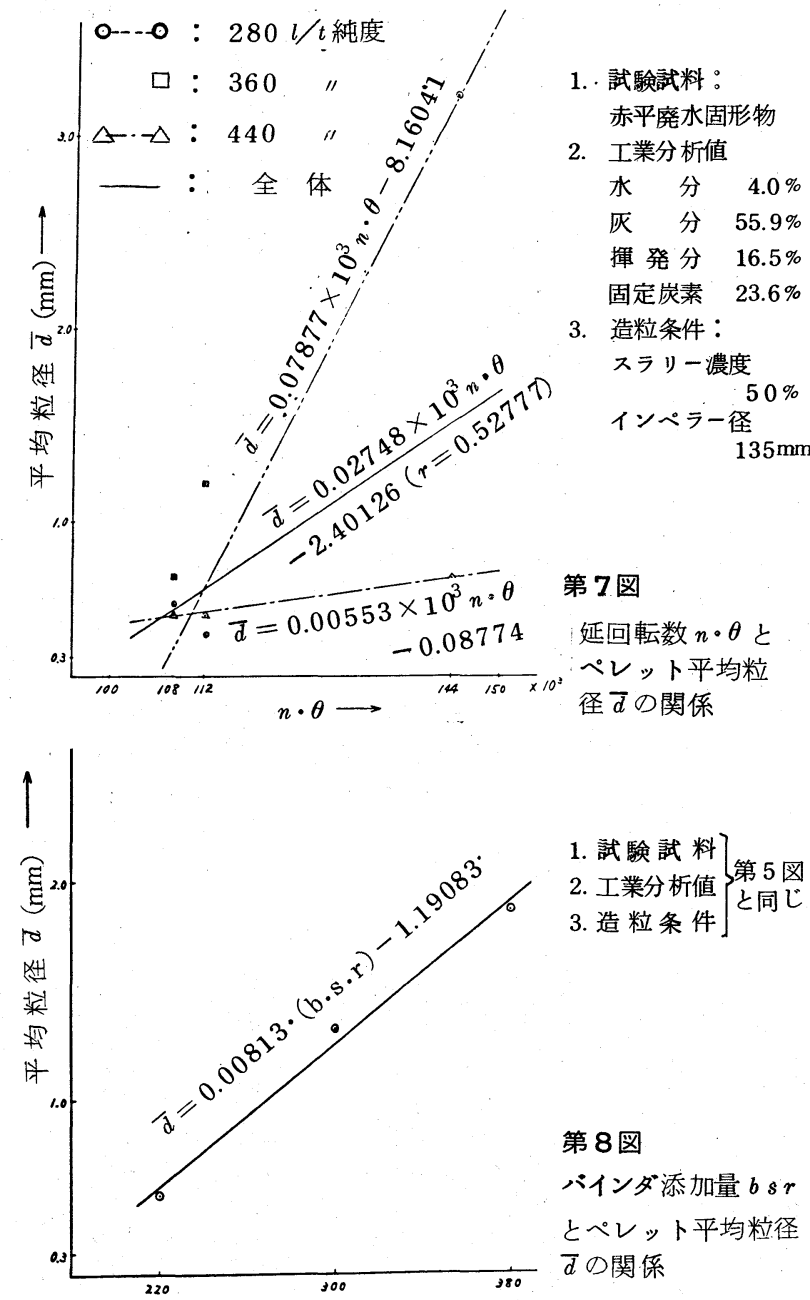

1. 試験試料 7 第 5 図 2. 工業分析值

\section{第 8図}

ハインダ添加量 $b s r$ とペレット平均粒径 $\bar{d}$ の関係

インダ添加量 b.s.r ( $l / \mathrm{t}$ 純度 $)$
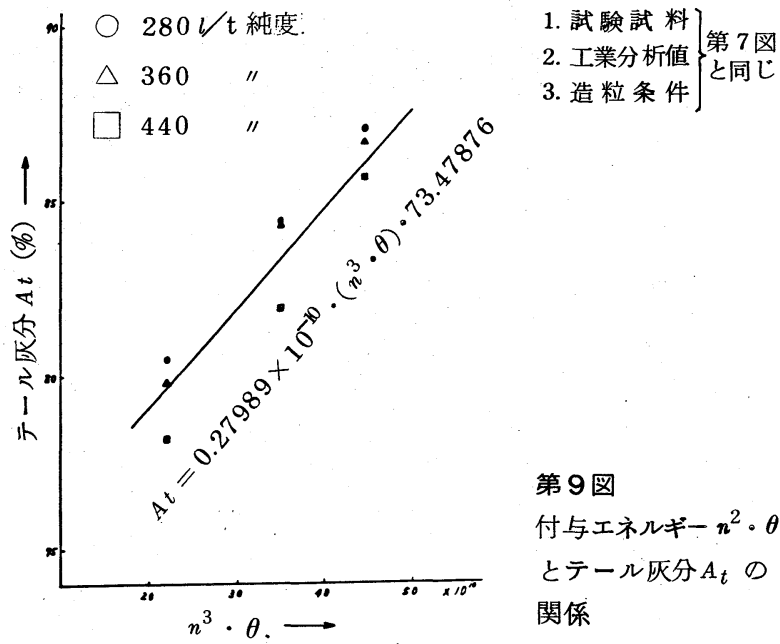

る）の増大は，脱炭効果を上げる(第 9 図に示す)。

(7) バインダ添加量の増大は脱炭効果を下げる(第10図に示す)。

（8）バインダ添加量の増大はペレット歩留を下げる(第11図に示 †)。

（9）ペレット平均粒径の増大は粒径のバラツキの度合を増す（第 12 図《示す)。

(10)ペレット歩留の向上は脱炭効果を上げる(第 13 図に示す)。 (11) ペレット歩留の向上はペレットの品位を下げる(第14図に
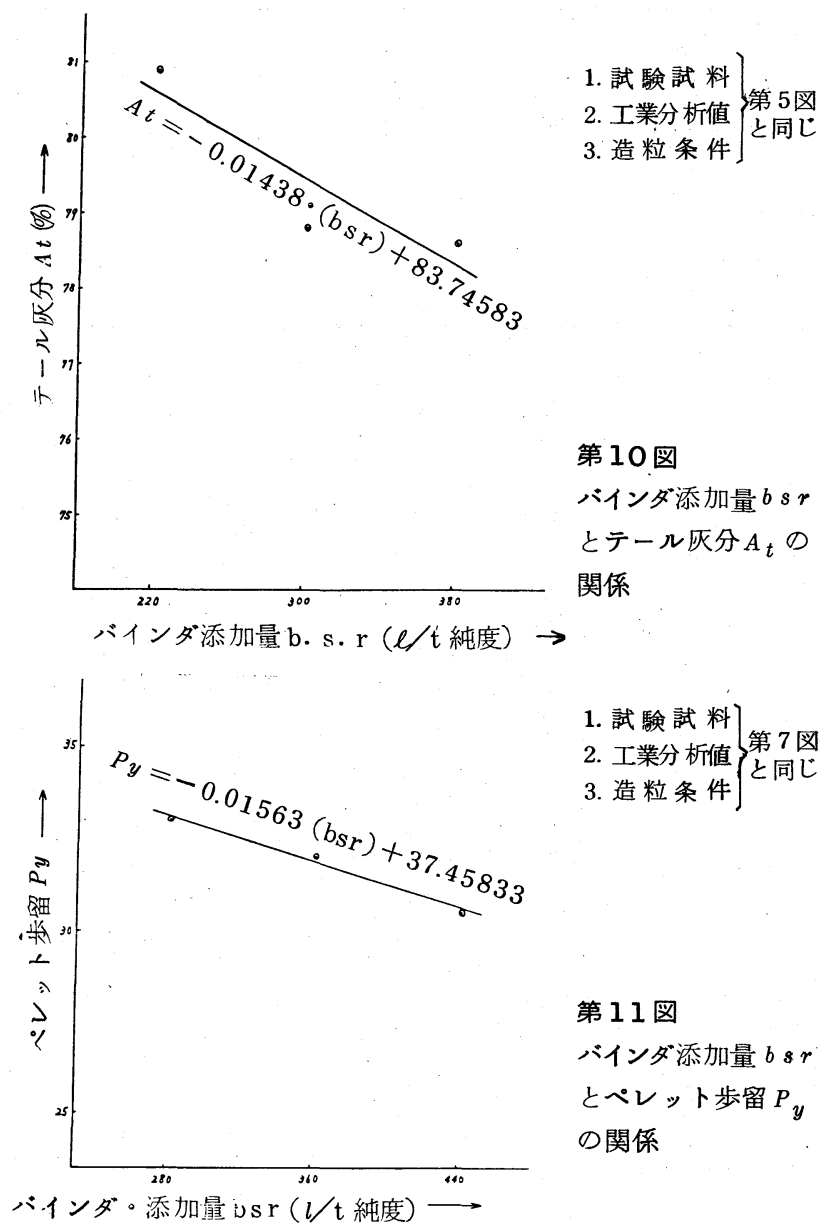

1. 試験試 料

2. 工業分析値 第 7 図 3. 造粒条件と同し

第 11 図

バインダ添加量 $b s r$ とペレット歩留 $P_{y}$ の関係

1. 試験試 料

2. 工業分析值 第 5 図 3. 造粒条件 と同し

標準偏差は，下記粒度 範囲の重量分布によつ た。

粒度範囲 $(\mathrm{mm})$ $+4.76$ $4.76 \sim 4.00$

$4.00 \sim 2.83$

$2.83 \sim 2.00$

$2.00 \sim 1.19$

$1.19 \sim 0.50$

$-0.50$

第12図

ペレット平均粒径 $\bar{d}$ とバラッキの関係 示す)。

ペレット平均粒径 $\bar{d}(\mathrm{~mm}) \longrightarrow$

(12) 廃水固形物の品位の向上は造粒速度を助長する一方, ペレ ットの破壊速度も助長する(第 15 図に示す)。即ち適切な造粒時 間の選定が必要である。

(13) 適切な造粒時間とは造粒速度とペレットの破壊速度が平衡 する以前の, 即ちぺレットの整粒化が進む以前の, ペレットの平 均粒径が最大值を示す時間近傍である(第 15 図参照)。乙の付近 で脱炭効果も最良值を示す。

以上の知見を基に連続試験を実施する上で，基礎的な未解明な 問題点を整理すれば, 次の通りである。

（1）微粉炭とバインダの付着仕事の最重要因子である石炭粒子 